\title{
THE COLONIAL REVERBERATIONS OF LIVRARIA DO GLOBO TRANSLATIONS IN 1930S BRAZIL
}

\author{
Vanessa Lopes Lourenço Hanes ${ }^{1}$ \\ -Universidade Federal Fluminense, Rio de Janeiro, Rio de Janeiro, Brasil
}

\begin{abstract}
This paper investigates early postcolonial Brazil through the lens of one of its most prominent publishers, Livraria do Globo, seeking to define the links between literary translation and supposedly receding colonial power. In an analysis of nine English-language translations by this publisher in the 1930s, what at first made little sense in terms of coherent translation policy actually evinced a still powerful colonial influence. France, Portugal and England seemed to struggle within the pages of these books, while Brazilian nationalism and the systematization of Brazilian Portuguese simultaneously unfolded.
\end{abstract}

Keywords: Brazilian Portuguese; Nationalism; Postcolonialism; Translated mass literature

\section{AS REVERBERAÇÕES COLONIAIS DAS TRADUÇÕES DA LIVRARIA DO GLOBO NO BRASIL DA DÉCADA DE 1930}

Resumo: Este artigo investiga o começo do Brasil pós-colonial sob a ótica de uma de suas editoras mais proeminentes, a Livraria do Globo, procurando definir as ligações entre a tradução literária e o poder colonial supostamente em retrocesso. Em uma análise de nove traduções de textos originários de língua inglesa lançadas por aquela editora na década de 1930, o que inicialmente parecia fazer pouco sentido em termos de coerência de política editorial na verdade acabou por evidenciar uma influência colonial ainda bastante presente. França, Portugal e Inglaterra pareciam travar um embate nas páginas desses livros, ao mesmo tempo em 
que nelas também se viam os primeiros desdobramentos do nacionalismo brasileiro e da sistematização do português brasileiro.

Palavras-chave: Português brasileiro; Nacionalismo; Pós-colonialismo; Literatura de massa traduzida

\section{Introductory Note}

Monteiro Lobato, an important author, translator and publisher in early $20^{\text {th }}$ century Brazil, said about himself and fellow Brazilians: "we are a people of colonial mentality. We were born a colony and have so far only conquered political independence. Economically, spiritually, mentally and scientifically, we are still a colony" (1951, 102, our translation). ${ }^{1}$ Such an admission by a promoter of Brazilian nationalism serves to illustrate the generally perceived strength of the colonial grip long after Brazil had become nominally independent from Portugal. The colonial system reverberated everywhere, including in translated literature, as this text sets out to demonstrate.

The initial objective of this study was to collect and analyze a corpus of English-language novels translated into Portuguese in 1930s Brazil, looking for any prevalent norms during the period (Toury). The idea was to focus on a certain subset of the process of exchange between Brazilian and foreign cultures (a specific set of books) to find patterns in cultural transfer (D'hulst). However, it soon became clear that such a study would involve more than textual analysis of a handful of books, since it was obvious that the corpus would actually demonstrate translation irregularities rather than norms. What was not clear was whether there actually was some logic behind the apparent randomness. This paper, therefore, became a broader investigation of early postcolonial Brazil through

\footnotetext{
${ }^{1}$ Somos um povo de mentalidade colonial. Nascemos colônia e até agora só conquistamos a independência política. Econômica, espiritual, mental e cientificamente, continuamos colônia.
} 
the lens of one of its most prominent publishers, Livraria do Globo, uncovering links between literary translation and presumably receding colonial power.

\section{A bit of Brazilian history}

A brief review of Brazilian history and the development of the publisher will help set the context for analysis of the translated corpus. In 1500 Brazil became a Portuguese colony, a purely exploitative relationship that discouraged not only higher education but general literacy, Thus cultural goods were hardly a priority. This state of affairs partially changed at the beginning of the $19^{\text {th }}$ century when, for fear of Napoleon's impending invasion, the Portuguese Prince Dom João VI and his mother Queen Maria fled to Brazil along with ten to fifteen thousand members of the Portuguese nobility. This was the dawn of a new era, both culturally and politically, for colonial Brazil. The Portuguese brought their libraries, their European fashion and their treasures to South America where there was little resembling an upper class. Gomes explains that the Portuguese nobility simply pretended that they were still in Europe, mimicking the habits of Versailles, Vienna and Madrid, while ignoring the extreme poverty surrounding their ballrooms, where the slave-based society was becoming unsustainable. It was in such a context that Brazil was ostensibly liberated from colonial status: in 1889 , one year after slavery was abolished, the country was proclaimed a republic.

However, the republic did not come about to be due to the victory of republican ideals, but because the Portuguese monarchs simply could not resolve the country's many burdensome problems (Gomes). The monarchy had insufficient popular support to continue, although the idea of a Republic was met with a lukewarm reception. There was no consensus among the general population about even Dom Pedro II, the central figure of Brazilian monarchy throughout the latter half of the $19^{\text {th }}$ century: some considered him 
a tyrant and an enemy of public institutions (a view encouraged by the republicans), while others depicted him as an affable intellectual who truly loved Brazil. Even Marechal Deodoro da Fonseca, who would eventually proclaim Brazil to be a republican state, publicly waffled in his political position: more than once he sided against the Republic and proclaimed his faithfulness to the emperor. Thus, Brazil became a republic without substantial grassroots support.

Perhaps due to this, many years after the Republic had been proclaimed Brazilian society was still divided regarding its status as an ex-colony. Some wished that the Republic had never been proclaimed, while others thought nothing could have been better for the country. Some saw Portugal with understandable disdain after centuries of exploitation, while others still looked to Europe as the source of civilization and culture. A drive arose amongst nationalists to explore what was truly Brazilian. According to Velloso, São Paulo's Week of Modern Art in 1922, which is considered the beginning of modern Brazilian culture, was but the tip of a nationalistic iceberg that reverberated far beyond Rio de Janeiro and São Paulo, promoting debates and social movements in a number of states. Furthermore, in the 1930s Brazil's international relations were changing as a reflection of updates in world dynamics: the cultural currency of English-speaking nations was increasing, while French culture and language, which had for a long time been held synonymous with the good, the fashionable and the desirable, were losing their grip on the Brazilian imaginarium.

Thus, Brazil was still looking for a post-colonial cultural identity, and its politics were likewise in turmoil at the end of the 1920s. In this period, the Brazilian economy was largely agricultural, with coffee as its main export product. When the American stock market crashed in 1929, Brazil also suffered: coffee plantation owners ${ }^{2}$ lost their political influence and could not

2 The period of political influence of these agricultural magnates was called the Política do café com leite (Coffee with milk policy), in reference to coffee growers from the state of São Paulo and dairy producers from the state of Minas Gerais.

Cad. Trad., Florianópolis, v. 39, no 2, p. 95-115, mai-ago, 2019. 
immediately produce a presidential candidate from their region. The opposition sided with the military, and in 1930 a military coup placed Getúlio Vargas, from the southernmost state of Rio Grande do Sul, in the presidency, beginning the period called the Second Republic. Vargas ruled from 1930 to 1945 and again from 1950 to 1954 (this time democratically elected), with a strong nationalist and anticommunist emphasis.

\subsection{Livraria do Globo and the dawn of publishing in Brazil}

With these events unfolding, what would become one of the most important Brazilian media enterprises was established while Brazil was still under imperial rule: Livraria do Globo (henceforth, Globo) was founded in 1883 in Porto Alegre, Rio Grande do Sul (where Vargas had been born the year previously). As its name indicates, it was at first a livraria, that is, a book shop, as well as a press-for-hire by third parties. However, at the beginning of the $20^{\text {th }}$ century Globo began publishing its own editions sporadically and in 1928 it went into regular production, beginning with magazines and almanacs, and moving on to translated and national literature. In fact, its publications covered a broad range of genres: self-produced encyclopedias and dictionaries (which would become important Brazilian reference material), national novels (mainly regional stories packed with local color from Rio Grande do Sul), as well as translations of canonized foreign literature (such as Proust), philosophy, and pulp fiction (including an impressive selection of detective fiction). Globo's headquarters soon became a meeting spot for intellectuals, poets, politicians and other professionals. President Vargas himself was openly friendly with the company and paid regular visits (Amorim).

The importance of Globo and the very few other publishing houses from Brazil at that time (such as Monteiro Lobato's Companhia Editora Nacional) is better explained by the fact that until World War I Brazilian books, except for didactic materials, were almost exclusively printed either in Europe or by European 
publishers with installations in Brazil. Renowned Brazilian writer Machado de Assis, for example, was published by Garnier in France. With respect to France's influence in the Brazilian book market, Wyler points out that throughout the $18^{\text {th }}$ century in all Brazilian libraries, both private and monastic, French originals and indirect translations through French prevailed, a situation that was only exacerbated after the Portuguese nobility arrived. In the $19^{\text {th }}$ century, French cultural domination in Brazil was quite strong: the wholesale exportation of French books to Brazil was accompanied by the establishment of French bookstores and publishers who commercialized originals and translations. For example, in 1833 Casa Garraux, in São Paulo, offered 473 titles in its catalogue, 215 of them in translation (one from Italian, one from Spanish, one from German, nine from English and 203 from French). Therefore, as Wyler makes clear, the Brazilian worldview was based on three centuries of systematic exposure to both Portuguese and French cultures, which also affected the way Brazilians saw translations.

It was only in the 1930 s, under the new administration of editor Henrique Bertaso, that Livraria do Globo began to invest heavily (though not exclusively) in translating titles from English. Distributed in ten different collections according to genre, it was hypothesized that these translations could provide insight into this fascinating era of cultural shifts and upheaval.

\section{A closer look at some of Globo's books}

Researching Brazilian literary history is a daunting task due to a general lack of interest in rare and collectible books, which makes it nearly impossible to find available copies for analysis. However, all 1930s Globo translations of English-language novels available in Brazilian online bookstores ${ }^{3}$ during the month of March 2017

\footnotetext{
${ }^{3}$ For the book search, I used the nationwide online network of booksellers, estantevirtual.com.br, which is similar to abebooks.com; the majority of the corpus came from a stock liquidation at a single shop.
}

Cad. Trad., Florianópolis, v. 39, no 2, p. 95-115, mai-ago, 2019. 
were collected, which, complemented with a prior acquisition, totaled nine titles. This corpus was analyzed in hopes of defining the contours of company translation policy during this decade, which could explain how this publisher positioned itself within, as well as influenced, the changing social, cultural and political landscape. Although no direct link with (post)colonial factors was initially expected, the data made it evident that such a connection was inevitable.

Each title was analyzed in what Lambert and van Gorp would call a preliminary stage, on both a macrolevel and microlevel. The microlevel analysis involved the initial and final chapters of each book. All paratextual aspects were also examined, although this was occasionally limited by the lack of original covers and/or introductory sections.

The following is a list of the included titles:

- The Black Abbot (O Abade Negro), by Edgar Wallace. First published in Britain in 1926 and translated by Suzana BurtinVinholes in 1932. Genre: detective story.

- The Murder of Roger Ackroyd (O Assassinato de Roger Ackroyd), by Agatha Christie. First published in Britain in 1926 and translated by Heitor Berutti in 1933. Genre: detective story.

- The Pilot: a Tale of the Sea (O Piloto), by James Fenimore Cooper. First published in the United States in 1824 and translated by Noah Moura in 1933. Genre: adventure/war novel.

- A Certain Dr. Thorndyke (O Incrível Dr. Thorndyke), by R. Austin Freeman. First published in Britain in 1928 and translated by L. Cunha in 1933. Genre: detective story.

- The Prisoner in the Opal (O Prisioneiro da Opala), by A.E.W. Mason. First published in Britain in 1928 and translated by Marina Guaspari in 1934. Genre: detective story.

- The Yellow Snake (A Cobra Amarela), by Edgar Wallace. First published in Britain in 1926 and translated by Érico 
Veríssimo in 1936. Genre: detective story.

- The Spy (O Espião), by James Fenimore Cooper. First published in the United States in 1821 and translated by Gilberto Miranda in 1938. Genre: historical adventure.

- Eyeless in Gaza (Sem Olhos em Gaza), by Aldous Huxley. First published in Britain in 1936 and translated by Miranda Reis in 1938. Genre: romance/semi-autobiographical novel.

- The Cartwright Gardens Murder (Um Cadáver no Jardim), by J.S. Fletcher. First published in Britain in 1926 and translated by Justino Martins in 1939. Genre: detective story.

Considering the size of the corpus, and since the aim of this study was not a complete systematic analysis of the translations but rather a focus on aspects directly related to the question of colonialism, the data were not subdivided in classes: a brief description follows of relevant findings at different levels, although not necessarily in the order proposed by Lambert and van Gorp, which both illustrates the randomness of translation strategies and establishes their connection with paratextual or extratextual elements.

From a preliminary point of view, a few regularities were observed in the corpus. The first is Globo's clear choice to focus on the distribution of non-canonized mass literature, such as detective stories, which became one of its trademarks in the 1930s. However, upon closer examination, the pretense of normativity fails even within the same genre. A second regularity seems to be a prioritization of British over American fiction, since only two American novels, both by James Fenimore Cooper, could be found (i.e., canonized literature over a century old by the time it arrived in Brazil). The available selection indicates that Globo had decided to direct the market away from French authors and towards Englishlanguage authors, although with an evident preference for those from Britain. This should not be completely unexpected since, by the 1930s, colonies and ex-colonies of Europe covered 84.6 percent of the planet (Loomba): Europe, therefore, spoke of old, traditional and lasting cultural power. 
That Europe was perceived as the cultural center was also corroborated by microlevel detail, which indicated that francophilia was hardly being purged, despite the general shift toward English. In the first lines of The Black Abbot, a library desk becomes a "bureau" (Hanes 5) in Brazilian Portuguese. The use of quotation marks in the translation shows not only that the term was not of common usage, but that there was a clear interest in emphasizing a French word. In The Murder of Roger Ackroyd, the narrator's name is changed from James to Jaques (5), a Brazilianized version of Jacques. ${ }^{4}$ In $A$ Certain Dr. Thorndyke, the term ensemble (7), which was also found in the original English, is kept in the translation, but with the addition of italics and quotation marks, once more emphasizing its foreign origin. The Prisoner in the Opal was set in the south of France, and French loanwords such as chateau (6) and belle (282) can be found throughout the translation. Eyeless in Gaza portrays the south of France as the most ideal and desirable place on earth (e.g., 490), and the main character mentions Proust as part of his reflections (12). Thus, sampling just a few pages, a notable French presence was observed in five of the nine novels selected for translation, either due to the plot, or to occasionally gauche insertions of French loanwords.

Thus, Globo's policy would seem to be a classic case of foreignization. However, the search for a center becomes more confusing upon realizing that while these translations seemed to privilege (and occasionally force) a French connection, they also included a considerable amount of English-driven foreignization. In The Black Abbot, "hall" (7), "stores" (9) and "sport" (9) appear, with Miss repeatedly used to refer to one of the characters (7 and 277); in addition, Richard (5) and its nickname Dick (277) are used interchangeably to refer to the same character, an association

${ }^{4}$ The first French translation of this novel did not translate the English names, meaning that what was done in the Brazilian version was not the result of indirect translation, but rather was an attempt to pass for one, which could be called a pseudoindirect translation (see Hanes (B)).

Cad. Trad., Florianópolis, v. 39, no 2, p. 95-115, mai-ago, 2019. 
generally unknown by Brazilians to this day. In The Pilot, the spelling of whisky (6) is maintained as in English rather than the common domestication uisque. Moreover, highlanders (5) are mentioned as if the term were common knowledge, and the original names of certain places (such as Devil's Grip, on 287) are used. A Certain Dr. Thorndyke contains footnotes to explain terms such as Slave coast (page 8) and cab (10), left in English in the translation. The Yellow Snake presents several instances of $\mathrm{Mr}$. (see 10, 11 and 254) as a courtesy title, rather than the Portuguese alternative Sr. (Senhor). Furthermore, match (254) appears in italics with no translation. In The Spy, places such as Lundy's Lane (401) are not translated, which compromises immediate understanding of the text in Portuguese (both the possessive and the term lane would pose difficulties to monolingual Brazilian readers); in addition, "leader" (20) appears with no explanation or translation, although mile is translated as milha (11) despite the use of the metric system in Brazil. Eyeless in Gaza presents at least one possessive in English, Benger's food (10), with no further explanation. Furthermore, the epigraph, a line from the John Milton poem that inspired the novel's title, appears in English, which would thus set the tone only for those who could already read the work in the original language. In The Cartwright Gardens Murder, the use of "shilling" (7) and "yankee" (220) as well as the untranslated street names (e.g., Gresham Street, 6) serve to indicate the Anglo roots of the story to Brazilian readers. These examples demonstrate that, sometimes even within a translation that presents clear overtures to French, there may also be found elements, sometimes unnecessary from a functional point of view, to indicate British or American origin.

However, a concomitant tendency to domesticate was also evident, which confounds foreignization as a general policy. In The Murder of Roger Ackroyd, probably because Brazilians do not consider bacon and eggs to be breakfast food, the translator changes Jaques' meal from breakfast to lunch (5), despite the fact that this alteration compromises the plot to some extent. Furthermore, the Portuguese usage involves regionalism: the second person 
address $(t u)$, which is common in the south, is used instead of the third person (você), which is generally used in the rest of the country, not only throughout in Christie's bestseller (see 5, 6, 7, 8 , 9), but erratically in translations of The Pilot $(286,287), A$ Certain Dr. Thorndyke (5 and 10), The Yellow Snake (page 10), Eyeless in Gaza (490) and The Cartwright Gardens Murder (219 and 221), demonstrating not only a tendency to domesticate but to also regionalize the texts, marking them as a product of Rio Grande do Sul. Proper names and courtesy titles such as Sir and Miss tend are generally translated throughout the corpus (albeit not uniformly, as previously shown in The Black Abbot and The Yellow Snake). In The Cartwright Gardens Murder, the Post Office Savings Bank becomes the Caixa Econômica, a federally-operated Brazilian bank (7). Finally, further domesticating efforts included the use of Brazilian idiomatic expressions, such as "pé-de-meia" (7) to translate "a small store of saved money" in The Cartwright Gardens Murder.

The racial overtones of colonial culture present in a number of the originals, i.e. the depiction of natives from certain nations as culturally and/or intellectually inferior, were carried over into in the translations. In $A$ Certain Dr. Thorndyke, a white character is described as belonging to a superior race (page 7), which was literally translated as a raça superior. "Queer Mongolian folk" in The Yellow Snake (Wallace 6) was also translated literally, as was the following description, "Fing-Su was tall for a Chinaman and good-looking by European standards. But for the characteristic slant of his black eyes there was nothing that was typically Chinese about him." (ibid. 7). Despite the fact that the prejudice originated in the colonizer's literature, Globo's selection of such novels for publication in Brazil indicates not only the general strength of the "whitening policy" (i.e., eugenics) that was openly defended by many (see Jaccoud), but that those in command at Globo felt they were on the side of colonizers and saw fit to propagate (at least some aspects of) their agenda. In The Black Abbot, only a single character's name is translated: the house servant Thomas is called 
Tomaz (5), perhaps since a more recognizable name would be more appropriate for a subaltern who, by the way, was also depicted in an unfavorable light both intellectually and morally. In the source text of $A$ Certain Dr. Thorndyke, both white and black characters speak in non-standard English. However, in the Portuguese version only the African character, again a subaltern, does not speak 'correctly' (6 and 10). This also demonstrates that, contrary to what might be expected, written representations of non-standard language in translation date back almost a century in Brazil. It is also one example of how, for an entire century, the discourse of white characters has been elevated to normative standards in translation, even when it was not so in the originals, while black characters have been represented using variations with less social prestige, even within the same story (see also Hanes (A)).

Although in this corpus France and England seem to be the most prominent cultures in the mind of the translators, Portugal is not completely absent, since Portugal and Brazil still shared many terms and even grammatical structures that have since fallen out of use in Brazil. The words patrícios in The Spy (18) and rapariga in The Cartwright Gardens Murder (225) are but two examples. It is true, however, that Portugal rarely appears in the sample, and when it does, it is in a negative light: in the opening of The Yellow Snake, a supposed Portuguese architect is ridiculed for being drunk and incompetent (5). Once more, though the worldview is that of the author, the selection of such a novel, with no omission or attenuation of its content in translation, must be considered a purposeful act by the publisher. The disregard for Portuguese approval could be partially explained by the fact that the cultural tables had been turned at that moment: six of the nine novels (all except The Prisoner in the Opal, The Yellow Snake and The Pilot) mention Globo's exclusive rights for translation both in Brazil and in Portugal. This sets Brazil in a curious position: the ex-colony that had been systematically denied education became, less than half a century after independence, an exporter of cultural goods (of European origin) to its former European colonizer. 
The sample also corroborates Veríssimo's account of the state of the Portuguese language at the beginning of the $20^{\text {th }}$ century, i.e., there was still no established orthography in either Brazil or Portugal. Each publishing house and even individual writers and translators developed their own style, or were fully erratic in their spelling. Thus, different spellings were found for the same word in different novels, or even within the same one, such as medo vs. mêdo (8 and 402, respectively) in Eyeless in Gaza, or detective vs. detetive ( 7 and 281, respectively) in The Prisioner in the Opal, as well as spellings that are no longer in use, such as daquellas (5) and azues (6) in The Black Abbot; cosinheira (7) and discreção (6) in The Murder of Roger Ackroyd; and quasi (5) and hespanhois (6) in The Pilot.

The nonstandardized spelling is only one aspect of a greater editorial trend throughout the corpus: there is also an apparent lack of final revision, which resulted in easily-preventable incongruities, which included, besides the above-mentioned spelling errors, more serious cases that would cause confusion to the average reader: the same place is called both Quinta do Rei (7) and King's Abbot (274) in The Murder of Roger Ackroyd; in The Pilot, the same character is called Cecília (282) and Celina (287); and in The Spy, the same character is referred to as Wharton (13) and Harton (14).

Another microlevel characteristic that stood out in the corpus was consistent overly literal translation choices. As previously mentioned, in The Black Abbot, the name Dick is used interchangeably with Richard without the necessary explanation, apparently for no other reason than that it was so in the original. In Eyeless in Gaza, beach pyjamas, the precursor to the swimsuit, which had become popular by the 1920s due to the influence of Coco Chanel (Parkinson), is translated as pijama de praia (9), although no direct evidence could be found that such a fashion ever made it to Brazil, which could have resulted in further reader confusion.

However, beyond the textual details, Globo's translations also serve as a curious example of ghost translation in Brazil: Érico Veríssimo, one of Globo's editors who would go on to become a 
respected Brazilian writer, also translated for them (in this corpus, The Yellow Snake was credited to him). However, according to Amorim, Veríssimo admitted that he used the pseudonym Gilberto Miranda for many of his translations (to whom Cooper's The Spy is credited on the title page). He used this pseudonym for works he preferred not to have his name associated with, mostly for original texts he considered unworthy of translation but was obliged to do for financial reasons, as well as to pose as a "mediocre" author (Amorim 81) dabbling in genres from literary criticism to fashion, politics, history, psychology, etc. This strategy had been previously used in America and Europe by writers such as the Brontës, Dickens, Washington Irving, and even Benjamin Franklin.

The corpus' paratext also indicates Globo's means of nationwide distribution during this period: telegraph orders. All the books have clear explanations on how to place an order via telegraph for any publication in its catalog. A number of the books in the corpus also contained a list of titles recently published by Globo with a specific code number to facilitate such orders. Thus, there was a technological dimension to the company's general experiment in modernization.

Globo was also uncertain about the degree of publicity to give to their authors, since they published a mix of canonized/vanguard literature and authors who were obscure even in their culture of origin. Although $A$ Certain Dr. Thorndike mentions nothing about its author, an inner flap reports that Globo had acquired the rights to publish works by a German author named Karl May. May is also promoted on the back flap of The Yellow Snake, where he is called "the German Jules Verne". The back cover of this book promotes both May and the works of Western fiction writer Zane Grey, perhaps due to the popularity of Westerns in the cinema. In The Spy, both inner flaps were used to praise R. L. Stevenson's Prince Otto, published in Globo's most illustrious collection, called Coleção Nobel. The back cover of The Spy, however, is used for quite a different purpose: to promote a novel by the above-mentioned Érico Veríssimo entitled Viagem à Aurora do Mundo. The Spy 
also contains an unusual element both for Globo and for books published in Brazil at that time: a translated four-page introduction by literary critic and publisher Alec Waugh. Finally, Eyeless in Gaza, the only title from the Coleção Nobel in the corpus, features a full-page photo of Huxley.

Although Globo usually gave credit to their translators, illustrators were for the most part anonymous: the only novel to mention the name of the cover artist was Eyeless in Gaza. Nevertheless, in a study on Globo illustrators in the first half of the $20^{\text {th }}$ century, Ramos defended their important cultural role in modernizing the national artistic panorama, while also citing critical voices such as Italo-Brazilian artist Ângelo Guido, who openly called the São Paulo modernist movement an empty shell, a spiritless salad of European Futurism, Cubism, Expressionism and so forth (see Ramos 195). In fact, these trends are quite apparent (as well as intermingled) in the cover art of the sample. However, regardless of its coherence or originality, the cover art demonstrates the degree to which the new aesthetic values of the Brazilian modernist (or rather, modernizing, as Ramos puts it) movement actually depended on the culture of the colonizers, despite the movement's ultranationalist undercurrents.

\section{Final remarks}

In a historical period full of contradictions, when one of the first nationwide publishers of popular fiction was expressing equally contradictory translation norms, it should not be ignored that "translation is not an innocent, transparent activity but is highly charged with significance at every stage" (Bassnett and Trivedi 2). With this in mind, the things that have been observed in this corpus of Livraria do Globo translations reveal much about early post-colonial Brazil. However, what exactly are they saying? The first point is that no steady norms regarding literary translation could be discerned because Brazilian culture, including Brazilian 
Portuguese, was unconsolidated in the 1930s. Moreover, the publisher was still establishing its own markets and organization model. What can be seen in the translations, however, are the effects of a strong colonial mentality and haltering efforts to break free from it, which lead Lobato to declare (as mentioned above) that "...we are still a colony".

While both Vargas' government and the modernist movement promoted extreme nationalism, the movement's effects in this corpus still seem weak compared to the colonial baggage, which resonates with Benedict Anderson's conclusion that "in the case of colonized peoples, who have every reason to feel hatred for their imperialist rulers, it is astonishing how insignificant the element of hatred is in these expressions of national feeling" (Anderson 142). Although a degree of antagonism against Portugal was indeed apparent, it appears that Globo's 'revenge' was to simply switch European patrons. This should not come as a surprise, however, since Brazil's young literary and cultural system would naturally tend to expand its repertoire by borrowing from other older, previously available systems (Even-Zohar).

Thus, side by side with heavily domesticated translations such as The Murder of Roger Ackroyd, Globo fawned upon the grandeur of French Europe with pseudoindirect translation (e.g. Jaques for James). Although, politically speaking, Brazil had never been a French colony, it had been so culturally for many decades, and this example of a falsified French origin demonstrates the vigor of this cultural fiefdom well into the 1930s.

Nevertheless, this external point of reference was also shifting towards the Anglophone world; the selection of Anglo-American texts and the profusion of English-language elements in the translations should not be very surprising, either, in light of the current political and economic developments. Lambert explains that, in cases of sudden political and social changes, translation activity tends to search for its rules and values in the dominant political environment. Thus, after the 1930 military coup, President Vargas's positive relations with the USA, particularly regarding 
economics, could explain why Globo not only began translating English-language originals, but heavily foreignized them. Such a tactic would not only serve to ingratiate themselves with their powerful friend and protector, but to escape his panel of censors as well: all cultural products during the regime were examined by the Departamento de Imprensa e Propaganda (Department of the Press and Advertisement), and only content deemed safe and commendable was cleared for publication. Moreover, the heavier investment in British rather than American literature might be ascribed to the fact that America was a successful colony, but a colony nonetheless.

The changing orthography of Brazilian Portuguese observed in the translations showed the beginnings of systematization, a testimony to the nation's struggle to give shape to its own language. Although Brazilian otherness compared to Portugal cannot be denied (Bandia), these translations are nonetheless in a colonial language, one that succeeded in extinguishing the Tupi-based Lingua Geral that had been spoken throughout Brazil since the end of the $17^{\text {th }}$ century and in marginalizing the many other indigenous languages. Nevertheless, the linguistic rift with European Portuguese has since become more accentuated, such that certain linguists (e.g. Bagno) would defend the idea that it is no longer the same language.

Globo's choice to translate, with no attenuation, negative depictions of Africans and Asians in novels they were selling to a country heavily populated by people of African or mixed-African descent would seem unwise, except for the fact that blacks were almost exclusively found among the illiterate masses and, therefore, ruled out as a target audience. In fact, as Niranjana (3) puts it, "[b]y employing certain modes of representing the other - which it thereby also brings into being - translation reinforces hegemonic versions of the colonized". Thus, in a mainly mixed-race nation, representing Africans as savages perpetuated a view that the white colonizers, and their European civilization, were superior, even decades after slavery and imperialism had been officially abolished. The ridicule of China and Mongolia, who have never been under direct 
European rule, further reinforced the publishing elite's connection with the colonizers, despite, or perhaps due to, the waves of Asian immigrants arriving in southeastern Brazil in this period.

Whereas translation may not necessarily have been a "central act of European colonization and imperialism" (Cheyfitz 104) in Brazil, it has certainly served as one of the most efficient colonial strongholds over the Brazilian imaginarium, and as long as 'monolingual' Brazil feels the need to look abroad for cultural inspiration, whether France of yesterday or the USA of today, this will continue to be the case.

Although this study may have begun as a search for discernible norms in Brazilian translations of English-language novels, it discovered that the 1930s was a historical moment in which the plurality of translation choices defied classification. No label, such as predominantly foreignizing, domesticating, French-oriented, English-oriented, prevailed in this corpus, despite its limited size. However, what seemed nonsensical as translation policy served as consistent evidence of a still powerful colonial influence. France, Portugal and England seemed to struggle within the pages of these translations, while incipient Brazilian nationalism and Brazilian Portuguese unfolded around them. This clearly indicates a nation in search of an identity. Having been recently emancipated, it was seeking a basis, whether at home or abroad, upon which to reinvent itself. To what degree such self-colonization persists today and whether translation is playing any role in decolonization are questions that remain to be answered. 


\section{References}

Anderson, B. Imagined Communities: Reflections on the Origin and Spread of Nationalism. London: Verso, 2006.

Amorim, S. M. de. Em Busca de um Tempo Perdido: Edição de Literatura Traduzida pela Editora Globo (1930-1950). São Paulo: EDUSP, 2000.

Bagno, M. Português ou Brasileiro? (Um Convite à Pesquisa). São Paulo: Parábola Editorial, 2001.

Bandia, P. "Post-colonial Literatures and Translation." In Gambier, Y and Doorslaer, L. van. Handbook of Translation Studies. v. 1. Amsterdam: John Benjamins, 2010. p. 264-269.

Bassnett, S. and Trivedi, H. (eds.). Post-colonial Translation: Theory and Practice. London: Routledge, 2000.

Cheyfitz, E. The Poetics of Imperialism: Translation and Colonization from The Tempest to Tarzan. New York and Oxford: Oxford University Press, 1991.

D'hulst, L. “( $(\mathrm{Re})$ locating Translation History: From Assumed Translation to Assumed Transfer”. Translation Studies 5.2 (2012): 139-155.

Even-Zohar, I. “Polysystem theory.” Poetics Today 1.2 (1979): 287-310.

Gomes, L. 1989: Como um Imperador Cansado, um Marechal Vaidoso e um Professor Injustiçado Contribuíram para o Fim da Monarquia e a Proclamação da República no Brasil. São Paulo: Globo Livros, 2013.

Hallewell, L. O Livro no Brasil: Sua História. São Paulo: Edusp, 2005.

Hanes, V. L. L. (A). “Dois Pesos e Duas Medidas? Considerações Acerca da Tradução de Variantes Linguísticas Norte-americanas Negras e Brancas para o Português Brasileiro". Revista Belas Infiéis 6.2 (2017): 89-104. 
Hanes, V. L. L. (B). “A Test Case That Speaks Volumes: The Translations of Agatha Christie's The Murder of Roger Ackroyd and the Question of Written vs. Oral Discourse in Brazil”. In Pastwa, J. G. and Oyali, U. (Eds.). Norm-Focused and Culture-Related Inquiries in Translation Research: Selected Papers of the CETRA Research Summer School. Frankfurt: Peter Lang, 2016. p. 25-44.

Jaccoud, L. "Racismo e República: o Debate sobre o Branqueamento e a Discriminação Racial no Brasil”. In Theodoro, M. (Ed.). As Políticas Públicas e a Desigualdade Racial no Brasil: 120 Anos Após a Abolição. Brasília: Ipea, 2008. p. 45-64.

Lambert, J. "Literature, Translation and (De)colonization". In Hyun, T. and Lambert, J. (Ed.). Translation and Modernization. Tokyo: Tokyo University Press, 1995. p. 98-117.

Lambert, J. and Gorp, H. van. "On Describing Translations." In Hermans, T (Ed.). The Manipulation of Literature: Studies in Literary Translation. London: Croom Helm, 1985. p. 42-53.

Lobato, J. B. R. M. Mundo da Lua e Miscelânea. São Paulo: Brasiliense, 1951.

Loomba, A. Colonialism/Postcolonialism. London/New York: Routledge, 2015.

Niranjana, T. Siting Translation: History, Post-structuralism, and the Colonial Context. Berkeley/Los Angeles/Oxford: University of California Press, 1992.

Parkinson, J. "When Pyjamas Ruled the Fashion World". BBC News Magazine. 2016. Web. 2016. < http://www.bbc.com/news/magazine-35427892 >. 20 May 2018.

Ramos, P. A Modernidade Impressa: Artistas Ilustradores da Livraria do GloboPorto Alegre. Porto Alegre: Ufrgs Editora, 2016.

Toury, G. Descriptive Translation Studies and Beyond. Amsterdam: John Benjamins. 
Velloso, M. P. História e Modernismo. Belo Horizonte: Autêntica, 2013.

Veríssimo, J. 1977. Estudos de Literatura Brasileira: a Questão Ortográfica. São Paulo: Edusp, 1977.

Wyler, Lia. Línguas, Poetas e Bacharéis: uma Crônica da Tradução no Brasil. Rio de Janeiro: Rocco, 2003.

Recebido em: 05/12/2018 Aceito em: 27/03/2019 Publicado em maio de 2019

Vanessa Lopes Lourenço Hanes. E-mail: vanessahanes@gmail.com. ORCID: https://orcid.org/0000-0002-0413-0190 